\title{
EVALUATION AND SELECTION PROCESS OF SUPPLIERS THROUGH ANALYTICAL FRAMEWORK: AN EMPRICAL EVIDENCE OF EVALUATION TOOL
}

\author{
Shpend Imeri ${ }^{1}$, Khuram Shahzad ${ }^{2}$, Josu Takala ${ }^{2}$, Yang Liư ${ }^{2}$, Ilkka Sillanpää ${ }^{3}$, Tahir Ali $^{4}$ \\ ${ }^{1}$ High Level Training Institute, Macedonia \\ ${ }^{2}$ University of Vaasa, Faculty of Technology (Production Department), Finlandia \\ ${ }^{3}$ University of Vaasa, Faculty of Business Studies (Management Department), Finlandia \\ ${ }^{4}$ University of Vaasa, Faculty of Business Studies (International Business), Finlandia
}

Corresponding author:

Shpend Imeri

High Level Training Institute

Bulevard Braka Ginovski Nr. 46/office 3, 1230 Gostivar, Macedonia

phone: +389 42 222032

e-mail: shpend.imeri@hlti.org or shpend85@hotmail.com

Received: 12 March 2015

Accepted: 5 June 2015

\begin{abstract}
The supplier selection process is very important to companies as selecting the right suppliers that fit companies strategy needs brings drastic savings. Therefore, this paper seeks to address the key area of supplies evaluation from the supplier review perspective. The purpose was to identify the most important criteria for suppliers' evaluation and develop evaluation tool based on surveyed criteria. The research was conducted through structured questionnaire and the sample focused on small to medium sized companies (SMEs) in Greece. In total eighty companies participated in the survey answering the full questionnaire which consisted of questions whether these companies utilize some suppliers' evaluation criteria and what criteria if any is applied. The main statistical instrument used in the study is Principal Component Analysis (PCA). Thus, the research has shown that the main criteria are: the attitude of the vendor towards the customer, supplier delivery time, product quality and price. Conclusions are made on the suitability and usefulness of suppliers' evaluation criteria and in way they are applied in enterprises.
\end{abstract}

KEYWORDS

supplier evaluation, suppliers performance management, supplier selection model, principal component analysis, supply chain management.

\section{Introduction}

In today's highly competitive but also interrelated business environment, the effective selection of business partners is one of the most important issues, enterprises are dealing with. For the reason, companies face a stiff competition which forces them to focus on the improved quality, cost reduction activities, and improved lead time. Therefore, they need to be very efficient to meet the dynamic market requirements and to be open to change [1], low cost, high quality products and supplier satisfaction [2]. Increases of customer demands, supply/demand chain [3], advances of recent technologies, especially evolution in information and com- munication technologies [4], competition in a global environment [5], and increases in environmental consciousness [6] have forced enterprises to focus on better supply chain management [7]. Moreover, radical product and technology innovation demand manufacturer to turn back to the suppliers and the key partners in order to maintain their existing customer base [8]. Nowadays more than ever, businesses are depending on strategic relations with their customers and suppliers in order to create value-added systems that will give them a competitive edge in the market [9].

Most of the time vendors are being selected by companies based on three basic factors, their ability to meet some quality standards, their delivery 
schedule and the price they offer. However in modern management, one must take into consideration numerous other factors in order to succeed and establish a long-term relationship with its vendors and in order to consider suppliers as the best intangible assets of the organization [10]. From 1960s until today, scholars have published numerous articles focusing on the specific subject of supplier selection and evaluation methods. Most of them concluded that supplier selection process involves evaluation of different alternative vendors based on different multiple criteria. This process has undergone significant change during the past years, as technological capabilities have increased and new methodologies have been developed. Experts such as Charles A. Weber, and G.W. Dickson from 1966 until recently, discovered through surveys the various important selection criteria, some of which are quantitative and others qualitative. So far few attempts have been made to develop an analytical framework for the vendor selection process, which combine these criteria, in order to construct a model for vendor evaluation and selection [11].

\section{Need for research}

The growing role and dependence on suppliers within the company's business chain increases the need for objective assessment of supplier performance. In many cases it is not sufficient that suppliers are able to meet the materials and service requirements of today. Buyers also need to determine whether a supplier is sufficiently equipped to live-up to the company's long-term requirements and needs. In addition, it is necessary to know whether a supplier can guarantee sustained continuity of supply. Primarily, the purpose of this study is to construct an analytical framework for the vendor selection process. It combines quantitative and qualitative vendor performance indicators and based on the most important key factors of suppliers' evaluation to construct a model for vendor evaluation and selection. In order to decide what should be measured and to identify the most important performance indicators, it is necessary to define the term purchasing performance. Purchasing performance, according to Ohdar and Ray [12], is considered to be the outcome of purchasing effectiveness and purchasing efficiency. Purchasing effectiveness is the extent to which, by choosing a certain course of action, a previously established goal is being met. On the other hand purchasing efficiency deals with the relationship between planned and actual sacrifices made in order to be able to realize a goal that was previously set [13].
This study is important because it examines the buying attitudes of Greek SMEs as they have been cultivated by the selling behaviors of both domestic and foreign suppliers through the years. This initiative in this area aims to assist local companies by providing a framework for suppliers' evaluation and performance measurement.

The focus of this study is concentrated in the identification of the selection criteria that dictate for the successful evaluation of suppliers by various businesses in the marketplace. Additionally, it is expected that through this study the following objectives will be met in order to establish the type of evaluation factors that SMEs are using during the vendor selection process. Subsequently, the objectives of this study are; 1) to identify and analyze the most important performance indicators which are used by Greek-based (SMEs) enterprises in order to evaluate the performance of their suppliers, 2) to find out whether the selected theory is applicable to the local marketplace. In other words, whether the most important performance criteria employed in existing literature are related with those that will be answered by the Greek SMEs, 3) to assess whether these KPIs are industry dependent or not. In other words, whether they are applicable to all types of companies no matter the sector they belong to, and 4) to compare the emerged framework with existing ones.

The remainder of this paper is divided into four main sections. The first section provides a brief review of the relevant support literature. The second section outlines the methodology employed in the research with particular attention given to Principal Component Analysis (PCA). The third section provides a description of the resulting measures, a discussion on the validity and reliability of the measures, as well as a presentation of key findings. The fourth and last section includes the relevant conclusions and recommendations.

\section{Literature review}

The literature review is based on the basis for selecting the appropriate research methodology and will assist in achieving the research objectives. In the process of reviewing the literature, the authors focused on seven key issues, 1) supplier evaluation, 2) evaluation methods, 3) evaluation criteria (key performance indicators), 4) purchasing, 5) supplier relationships, 6) after sales, and 7) areas of investigation. By analyzing the theory, different areas were investigated in developing the analytical supplier selection framework see following Fig. 1. 


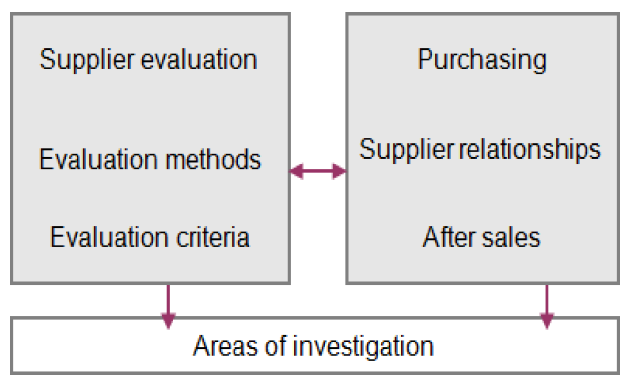

Fig. 1. Two sections of the analytical framework.

It is widely accepted that one of the most important responsibilities within the purchasing function of a business is the evaluation and selection of suppliers. In addition, it is well established that decisions for purchasing can be complicated and are often based on different criteria[13] and [14]. Therefore, since the 1960's the analysis of key performance indicators and the measuring of vendors' performance remains in the spotlight for numerous researchers and practitioners [15]. Supplier evaluation is a time consuming activity and therefore it is important to have clearly defined objectives in order to create value for the evaluating underlying company [16] and [70]. Since many years, several researchers have been identified some of the factors in their supplier evaluation models that are related to the successful evaluation of suppliers during the vendor selection process $[7$, 15, 17-19].

According to [20], the term "Supply Chain Management", which has been used by academics and practitioners for over 20 years, is defined as the integration of all activities needed in order to procure materials, transform them into intermediate goods and final products, and deliver them to customers. In other words, supply chains consists of all those links that are needed in order for a product to reach the final customer, with suppliers forming the key links between the raw materials to final product design and delivery [21]. It can be deduced therefore that vendor selection, evaluation, and their involvement is one of the most critical activities a firm should focus on [2]. On the other hand, the selection of inappropriate or unsatisfactory suppliers has the potential to unbalance a company's often delicate financial position (i.e. high cost) and upset it's operational (low product quality) infrastructure. Therefore, several researchers have highlighted the important role of supplier selection, and supplier's involvement in strategic decision making process [8, 22, 23], and [24] to achieve effective supply chain [25].

It is important to understand that the supply chain is a network trying to utilize fully the available resources in the best possible way. In this aspect in- stead of trying to optimize the firm operations, businesses should focus on the inter-organizational operations [26]. Moreover, Uzzi [27] stated that a balance in personal relationships between the linked organizations of a supply network should be found to create a good environment that provides stability to be established. Internal and external communication should be promoted to avoid the misunderstandings and a shared vision to be created [28]. Another important factor in a successful relationship is interaction between purchasers and technical staff of the company which becomes really important from the moment when products are developed increasingly sophisticated [28] and [29]. Even more benefits could be achieved if the suppliers become involved in the new product development process. As it can be seen, there is a correlation between supplier relationships and the supplier evaluation process [30] and [69]. Depending on the type of relationship wanted, certain questions should be part of the evaluation. It is therefore imperative for a company to clarify the type of relations it has with its suppliers as well as what type of relationships are desired for them [31].

A supplier evaluation should not only be used for selecting suppliers and evaluating bids, but also for motivating existing suppliers and initiating corrective actions [32, 33], and [34]. Since resources are often limited, not all existing suppliers are in a position to be evaluated. By comparing the different suppliers, the ones that would benefit the most from supplier development can be identified [35, 36] and [67]. In this process, supplier evaluation may be used as a tool to find areas in need of improvement. The evaluation can also be used as a basis for ongoing dialogue, where monitoring and learning are combined [36]. In a study by Lamming et al. [37], it was found that improved overall quality, better all-round service, improved delivery performance and relationships, were the top four benefits of evaluating existing suppliers, with reduced costs following closely behind. When asked, the suppliers listed the same benefits, putting improved relationships first. In a similar study by Tracey and Tan [38], it was found that the four dimensions of customer satisfaction and firm performance were positively affected when both choosing and regularly evaluating suppliers, with regard to quality, reliability and product performance. In the same vein, it was also found that firms usually focus too much on unit price, leading to worse performance. To achieve the best performance, the company should work jointly with its suppliers on product development and continuous improvements. Price is considered as a key performance indicator during the last many years and a switch to the cost 
perspective can be clearly seen [39] and [40]. Moreover, quality and delivery performance have always been presented as significant variables in all supply chain models [41-44].Innovativeness has also been referred from several researchers although only recently has gained some significance $[31,45]$, and [46, 68]. In addition, flexibility is a criterion that has started to appear in the models during the last decade [47]. Even though criteria such as continuous improvement [31] and personal relationships have followed the same trend, factors such as the importance of geographical location have decreased in significance.

According to Weber [48] there are a number of methodologies which have been developed from researchers and scholars to assist businesses in the evaluation process of suppliers. He identifies three main approaches for evaluation, namely: categorical, weighted point and cost ratio. The categorical method influences the company to initially decide the evaluation parameters of their suppliers. These parameters should then be assigned some form of rating system such as preferred, satisfactory or neutral rating. In the end, the sum of all parameters is calculated and the supplier with the highest score is chosen. This method is easy to implement and for this reason is appropriate for firms with limited resources. However, each parameter is equally weighted, so the results easily become unreliable [15]. The second approach identified by [15] is the cost-ratio method. The cost of each factor is calculated and is given as a percentage of total purchases. This cost is estimated for each potential supplier and the one with the lowest net adjusted cost will be chosen. The cost-ratio method is a very complex approach because requires a well-designed cost-accounting system to accurately generate the precise internal operating cost data. The final approach to vendor evaluation is known as the linear average of the weighted-point method. With this technique various factors, which are key to the company are weighted according to their perceived importance. Each weighting is then multiplied by the assigned performance score. Finally, a sum consisting of each criterion's result is calculated resulting in a final rating for each supplier. Even though the specific approach is more objective than the categorical method, the buyer can still exercise considerable judgment in determining the weighting for the evaluation criteria, as well as the numerical values for the vendors' performances. A comparison study of the three approaches by Chen et al. [49] reveals that the weighted point method can be used by most firms. Further, Presutti Jr \& Mawhinney [50] strongly recommend using a scorecard model for the assessment of suppliers.

\section{Methodology}

One of the most important elements defining the suitability of this study is the selection of an appropriate research methodology. According to Blaxter et al. [51], there are two basic research types: qualitative and quantitative. The distinction between them is not straight-forward and typical research often contains data of both types. In a quantitative research, data is usually collected through surveys and can be statistically examined. The result can then be generalized on a bigger population than examined. In qualitative research on the other hand, more detailed information about a single or a small amount of cases is collected. This information can then be reviewed using an analytical approach. According to Bryman [52], conclusions drawn from a qualitative study usually cannot be generalized to a larger population. Qualitative and quantitative data are usually used together and the use of one research strategy does not necessarily exclude the other type of data. In this study, a quantitative research strategy will be used but both qualitative and quantitative data is gathered, although the use of quantitative data will be dominant. Furthermore, Blaxter et al. [51] identified four basic approaches to research in the social sciences context: action research, case studies, experiments, and surveys. It should be noted that this classification is not meant to be definitive or exclusive, but simply recognizes the most common approaches used for small-scale research projects. In addition, Bryman [52] identifies four basic research techniques: the study of documents, interviews, observations, and questionnaires. This study, following the examples of the existing literature, will employ more than one method in the main body of the research, namely a survey in conjunction with a number of interviews, in order to obtain a more detailed perspective on the issues raised.

In order to be in the position to develop a suppliers' evaluation tool, which is the aim of this study along with determining the benefits earned when businesses apply a related tool to help them during the selection process, different aspects of the existing literature should be considered. The starting point for this framework should be to investigate the available literature, in order to see what kind of evaluation methods and criteria have been employed in the past. At the same time the reasons for which they were investigated and the benefits offered to the enterprises should be reviewed. In studying the theory, a number of different evaluation methods and criteria were discovered. The literature showed that before an evaluation method is applied, the key per- 
formance indicators must be chosen, through which an enterprise will evaluate its suppliers.

\section{Data collection and analysis}

Quantitative methods as well as qualitative methods were used for the analysis of the data obtained by the research. Moreover, for the purposes of the specific study both field and literature review research were carried out. Secondary data was obtained through literature research using online academic valid databases such as Emerald and EBSCO.

The primary sources of information were obtained through research in companies. The organizations participated in the research were selected according to their market share (large or small), size, human resources and industry. A major factor in the selection of the companies was the degree in which these manufacturing and commercial companies are dealing with a number of suppliers from Greece and abroad. During the pilot study companies importing products from other countries were preferred. 250 questionnaires were sent to purchasing managers, company owners, and managers through faxes or emails and 80 of them were received back which reflects a response rate of $32 \%$. A number of interviews were conducted mainly for clarification issues.

Principal Components Analysis (PCA) [53] and [54] with rotation to an orthogonal solution by the varimax method [55] was adopted as the main statistical instrument. According to Lewis-Beck [56], this method is the most commonly used in order to reduce the number of items in a survey questionnaire. The factorability of the data was tested with Bartlett's test of sphericity and the Kaiser-MeyerOlkin (KMO) measure of sampling accuracy [57]. Petroni \& Braglia [58] have used Principal Component Analysis in the development of a model for vendor selection. Reliability testing was undertaken using Cronbach's Alpha. This test of reliability coefficient is the most widely used [59] and [60]. The lowest value of Cronbach's Alpha is 0.7 that is generally agreed. Nevertheless, it is important to mention that this may decrease to 0.6 in exploratory research [61, 62], and [63], which fits in the specific study. One way ANOVA was used to test for differences between performance indicators and industry types. SPSS was the software used for the data entry and analysis.

\section{Findings}

In the distributed questionnaires, among other questions, the participants were asked to evaluate thirty key performance indicators. Both quantitative and qualitative indicators were included as suggested by Cebi \& Bayraktar [7], with the former being the majority. The surprise comes from the fact that the results revealed that the "attitude of each vendor towards each customer" indicator is considered as the most important of all (Table 1). This is an intangible (qualitative) performance indicator which could be attributed to cultural differences [64]. In contradiction with Dickson [65] survey who presents quality, delivery, and performance history to be the most important factors, [48] considered net price, delivery time and quality as the most important supplier selection criteria. In our case, delivery schedules are followed by net price and quality (both with a mean of 4.40$)$.

Table 1

Highest rated key performance indicators.

\begin{tabular}{l|c|c}
\hline Key Performance Indicators & Mean & Std. Deviation \\
\hline $\begin{array}{l}\text { The attitude of each vendor to- } \\
\text { wards each customer }\end{array}$ & 4.65 & .58 \\
\hline $\begin{array}{l}\text { The ability of vendors to meet } \\
\text { pre-specified delivery schedules }\end{array}$ & 4.62 & .54 \\
\hline $\begin{array}{l}\text { The ability of suppliers to meet } \\
\text { quality specifications }\end{array}$ & 4.40 & .76 \\
\hline $\begin{array}{l}\text { The net price, after discount and } \\
\text { freight charges }\end{array}$ & 4.40 & .76 \\
\hline $\begin{array}{l}\text { The ability of each supplier to be } \\
\text { flexible in changes of ordered vol- } \\
\text { umes }\end{array}$ & 4.37 & .85 \\
\hline $\begin{array}{l}\text { Reciprocal arrangements are sub- } \\
\text { stantial for the evaluation process }\end{array}$ & 4.23 & .83 \\
\hline $\begin{array}{l}\text { The credit policy offered by each } \\
\text { vendor }\end{array}$ & 4.13 & .89 \\
\hline $\begin{array}{l}\text { The level and degree of innova- } \\
\text { tion in terms of product design }\end{array}$ & 4.10 & .88 \\
\hline $\begin{array}{l}\text { Clear paths of communication } \\
\text { between my company and its sup- } \\
\text { pliers }\end{array}$ & 4.10 & .77 \\
\hline $\begin{array}{l}\text { The repair service given by each } \\
\text { vendor }\end{array}$ & 4.01 & 1.00 \\
\hline
\end{tabular}

Considering Dickson's survey and the fact that it took place during the 1960 's, the reciprocal agreements factor, which accounted as the least important factor, in this research respondents consider it as the sixth most important criterion. The least important factor for the participants in this survey is that of the labor relations of each supplier with a mean of 2.8 .

The companies participated in the survey come from four different sectors: manufacturing (26.3\% of the sample), commercial (45\%), services (22.5\%), and construction (6.2\%). One-way ANOVA testing was conducted in examining possible correlations between industry profiles and key performance indicators. Table 2 below shows that there are no significant correlations between the two groups. 
Management and Production Engineering Review

Table 2

One-way ANOVA test for differences between industry profiles and KPIs.

\begin{tabular}{c|c|c}
\hline Key Performance Indicators & $\mathrm{F}$ & Sig. \\
\hline 1 &, 350 &, 789 \\
\hline 2 & 1,435 &, 239 \\
\hline 3 &, 515 &, 673 \\
\hline 4 &, 060 &, 981 \\
\hline 5 & 1,265 &, 292 \\
\hline 6 & 1,908 &, 135 \\
\hline 7 &, 089 &, 966 \\
\hline 8 & 2,430 &, 072 \\
\hline 9 & 2,646 &, 055 \\
\hline 10 &, 824 &, 485 \\
\hline
\end{tabular}

Significant at $p<0.05$

Principal Components Analysis (CPA) has been selected in order to transform the original variables into a smaller set of linear combinations. In assessing the suitability of the data two tests were used: Bartlett's test of sphericity which should be significant $(p<.05)$ for the CPA to be considered appropriate and the Kaiser-Meyer-Olkin (KMO) measure of sampling accuracy with 0.6 suggested as the minimum value for a good analysis [57] and [54]. The results shown below in Table 3 allow us to proceed since the criteria for factorability are being successfully met $(p=.000$ and KMO index $=.759)$.

Table 3

One-way ANOVA test for differences between industry profiles and KPIs.

\begin{tabular}{c|c|c}
\hline $\begin{array}{c}\text { Kaiser-Meyer-Olkin Measure } \\
\text { of Sampling Adequacy }\end{array}$ & & .759 \\
\hline & Approx. & 768 \\
Bartlett's Test of Sphericity & Chi-Square & 351 \\
& df Sig. & .000 \\
\hline
\end{tabular}

Table 4

Total variance explained by each variable and emerged components.

\begin{tabular}{|c|c|c|c|c|c|c|c|c|c|}
\hline \multirow{2}{*}{ Component } & \multicolumn{3}{|c|}{ Initial Elgenvalues } & \multicolumn{3}{|c|}{ Extraction Sums of Squared Loadings } & \multicolumn{3}{|c|}{ Rotation Sums of Squared Loadings } \\
\hline & Total & $\%$ of Variance & Cumulative \% & Total & $\%$ of Variance & Cumulative \% & Total & $\%$ of Variance & Cumulative $\%$ \\
\hline 1 & 6.806 & 25.21 & 25.206 & 6.806 & 25.21 & 25.206 & 3.960 & 14.67 & 14.67 \\
\hline 2 & 2.223 & 8.232 & 33.438 & 2.223 & 8.232 & 33.438 & 3.128 & 11.58 & 26.25 \\
\hline 3 & 1.916 & 7.097 & 40.535 & 1.916 & 7.097 & 40.535 & 2.366 & 8.762 & 35.01 \\
\hline 4 & 1.589 & 5.886 & 46.421 & 1.589 & 5.886 & 46.421 & 2.332 & 8.639 & 43.65 \\
\hline 5 & 1.553 & 5.751 & 52.172 & 1.553 & 5.751 & 52.172 & 2.301 & 8.521 & 52.17 \\
\hline 6 & 1.355 & 5.020 & 57.192 & & & & & & \\
\hline 7 & 1.133 & 4.196 & 61.388 & & & & & & \\
\hline 8 & 1.035 & 3.832 & 65.220 & & & & & & \\
\hline 9 & 1.008 & 3.735 & 68.955 & & & & & & \\
\hline 10 & .924 & 3.424 & 72.379 & & & & & & \\
\hline 11 & .818 & 3.028 & 75.407 & & & & & & \\
\hline 12 & .740 & 2.741 & 78.148 & & & & & & \\
\hline 13 & .694 & 2.571 & 80.719 & & & & & & \\
\hline 14 & .649 & 2.402 & 83.121 & & & & & & \\
\hline 15 & .576 & 2.135 & 85.256 & & & & & & \\
\hline 16 & .507 & 1.877 & 87.133 & & & & & & \\
\hline 17 & \begin{tabular}{|c|}
.452 \\
\end{tabular} & 1.675 & 88.808 & & & & & & \\
\hline 18 & .432 & 1.602 & 90.410 & & & & & & \\
\hline 19 & .408 & 1.511 & 91.921 & & & & & & \\
\hline 20 & \begin{tabular}{|l|}
.362 \\
\end{tabular} & 1.342 & 93.264 & & & & & & \\
\hline 21 & .356 & 1.319 & 94.583 & & & & & & \\
\hline 22 & .345 & 1.278 & 95.860 & & & & & & \\
\hline 23 & .297 & 1.099 & 96.960 & & & & & & \\
\hline 24 & .245 & .908 & 97.867 & & & & & & \\
\hline 25 & .221 & .820 & 98.687 & & & & & & \\
\hline 26 & .183 & .677 & 99.364 & & & & & & \\
\hline 27 & .172 & .636 & 100.00 & & & & & & \\
\hline
\end{tabular}


In determining the number of components (factors) that best describes the underlying relationship among the variables, [54], in [57] recommends that "researchers adopt an exploratory approach, experimenting with different numbers of factors until a satisfactory solution is found". Nevertheless, Kaiser's criterion or, otherwise, the eigenvalue rule has been adopted which suggests that only factors with an eigenvalue of 1.0 or greater are retained for further investigation [54]. In some cases the Kaiser's criterion is resulting in the retention of too many factors and for that reason it has received a lot of criticism [57]. The five components that are retained in this study have eigenvalues ranging from 1.553 to 6.806 and explaining a total of 52.172 percent of the variance (Table 4 ).

The Rotated Component Matrix (shown in Appendix A) presents the loadings of each of the variables (performance indicators) on the five factors that were selected. All five components include a number of moderately strong loadings with just four cross loadings. The loading values in three out of the thirty variables were below the cut-off point of 0.4 so they did not load onto any of the five com- ponents. As indicated by [62] the testing procedure outlined by Tabachnick et al. [54], can exclude factor loadings of less than 0.50 from further analysis. This fact suits the present study in a sense that it provides some kind of simplicity in assigning a name to each component. Reference [57] suggests that by observing the highest loading variables on each of the components will assist in identifying the nature of the underlying latent variable represented by each component. Table 5 demonstrates the five extracted components with the variables they represent, along with Cronbach's alpha coefficients.

In order to determine the internal consistency of the measures the Cronbach's alpha coefficient was calculated. This reliability testing was undertaken for each component. The results, shown in the last column of Table 5, provide an adequate reliability as coefficient alphas of less than 0.60 is generally considered unsatisfactory [66] and [61]. The results improve the overall confidence of the adopted methodology, the actual data, as well as the conclusions being drawn concerning the validity of the developed measures.

Table 5

Total variance explained by each variable and emerged components.

\begin{tabular}{|c|c|c|c|}
\hline Component & Key Performance Indicator & $\begin{array}{c}\text { Impact of new Variable } \\
\text { Measurement }\end{array}$ & $\begin{array}{c}\text { Alpha } \\
\text { Coefficient }\end{array}$ \\
\hline A & $\begin{array}{l}\text { Procedural compliance with procedures, both bidding and operating } \\
\text { by each vendor } \\
\text { The way of management and organization of each vendor } \\
\text { The ability of suppliers to meet quality specifications } \\
\text { The position of each vendor in the industry } \\
\text { The labor relations record of each supplier should be exceptional }\end{array}$ & Management &, 8135 \\
\hline B & $\begin{array}{l}\text { Availability of training aids and educational courses in the use of each } \\
\text { product } \\
\text { A communication system with information on progress of orders pro- } \\
\text { vided of each vendor } \\
\text { Predefined agreed processes to identify and solve occurring problems } \\
\text { Warranties and claim policies of each supplier } \\
\text { Reciprocal arrangements are substantial for the evaluation process } \\
\end{array}$ & $\begin{array}{l}\text { Service } \\
\text { Quality }\end{array}$ & ,6806 \\
\hline $\mathrm{C}$ & $\begin{array}{l}\text { The impression made by each vendor in personal contacts } \\
\text { Closer relationships and reasonable tenure that can result in mutual } \\
\text { cost reductions } \\
\text { The geographical location of each vendor }\end{array}$ & $\begin{array}{l}\text { Customer } \\
\text { Relations }\end{array}$ & ,6318 \\
\hline $\mathrm{D}$ & $\begin{array}{l}\text { The net price, after discount and freight charges } \\
\text { The performance history of each vendor } \\
\text { The financial position of each vendor } \\
\text { The repair service given by each vendor } \\
\text { The production facilities and capacity of each vendor } \\
\end{array}$ & $\begin{array}{c}\text { Financial } \\
\text { Competitiveness }\end{array}$ & ,7013 \\
\hline $\mathrm{E}$ & $\begin{array}{l}\text { The ability of each supplier to be flexible in changes of ordered vol- } \\
\text { umes } \\
\text { The level and degree of innovation in terms of product design }\end{array}$ & $\begin{array}{c}\text { Flexibility } \\
\text { and Innovation }\end{array}$ &, 7072 \\
\hline
\end{tabular}


The vendor selection measurements developed by [18] were based on competitive concerns of the purchasing function. Criteria were employed from the existing literature and their empirical findings. They concluded that the five main competitive priorities for the purchasing function are cost, quality, delivery, flexibility, and innovation. Reference [17] model employed a list of factors for the automobile industry. For the selection process, he used a list of performance indicators divided into five distinct categories: cost, logistics, quality, development, and management. Cebi \& Bayraktar [7] developed an Analytic Hierarchy Process (AHP) model dividing the factors into four different categories: logistics, technology, business, and relationship. These factors were developed through observations of a Turkish manufacturing company.

The models of [17, 18], and Cebi \& Bayraktar [7] use four to five categories, as Dickson [65] has not divided the factors he surveyed into any distinct categories. The three developed models have one similar factor, logistics or delivery. Krause et al. [18] as well as Birch include the cost and quality categories. These models also use an innovation or development category that contains similar variables (indicators). Cebi \& Bayraktar [7] on the other hand use a business category which overlaps with Birch's management category. Although the framework developed in this study leverages greatly on Krause et al. [18] model regarding the categories incorporated in the models as well as the adopted methodology, the proposed model demonstrates improved applicability and further enhances overall confidence through supporting the validity of the developed measures.

\section{Conclusions}

This paper has proposed a model framework for supplier selection and evaluation. Various supplier evaluation methods were discussed and their suitability assessed. A supplier's evaluation tool was proposed and developed as a framework for future supplier selection. The survey involved 80 participating companies and the results of the research have shown that the most significant evaluation criteria used by Greek SMEs are the attitude of the vendor towards the customer, supplier delivery schedules, followed by product quality, and the product net price.

One of the major benefits that can be achieved is that the company performing suppliers' evaluation gets to know the suppliers in a more profound way, creating a good basis for future cooperation. By conducting this evaluation, the suppliers learn more about their customers' specific needs and de- mands. In addition, an evaluation provides suppliers with knowledge about areas in need of improvement, which they were unaware of, leading to improved performance. Nevertheless, the evaluation tool is only one step towards a better cooperation with the suppliers. The tool in itself will not lead to improvements per se. It is the use of the tool in combination with other activities that will lead to better performing suppliers.

The major contribution of this study is the empirical evidence gathered on the supplier selection process. The information collected and the findings of the study helped to close the gap between theoretical work and actual practice. The findings of this investigation are important in expanding the understanding of the variables that affect the supplier selection process, and specific information is provided addressing the criteria used by organizations for the supplier selection process.

In addressing future work, the framework could be expanded to include other corporate environments and companies based in other geographical locations, with the Balkan countries being perhaps closest to the original study in terms of both location and a social structure. The developed parts of the evaluation tool could be adapted on an ongoing basis, with the users incorporating further applied improvements arising from the continuous use of the framework, leading to the model's improvement.

\section{References}

[1] Qi R., Brdys M.A., Indirect adaptive controller based on a self - structuring fuzzy system for nonlinear modeling and control, Int. J. Appl. Math. Comput. Sci., 19, 4, 619-630, 2009.

[2] Aksoy A., Öztürk N., Supplier selection and performance evaluation in just-in-time production environments, Expert Systems with Applications, 38, 5, 6351-6359, 2011.

[3] Handfield R.B., Nichols E.L., Supply chain redesign: Transforming supply chains into integrated value systems, FT Press, 2002.

[4] Song M., Di Benedetto C.A. Supplier's involvement and success of radical new product development in new ventures, Journal of Operations Management, $26,1,1-22,2008$.

[5] Droge C., Vickery S.K., Jacobs M.A., Does supply chain integration mediate the relationships between product/process strategy and service performance? an empirical study, International Journal of Production Economics, 137, 2, 250-262, 2012. 
[6] Dickson G.W., An analysis of vendor selection systems and decisions, Journal of Purchasing, 2, 1, 517,1966

[7] Caridi M., Pero M., Sianesi A., Linking product modularity and innovativeness to supply chain management in the Italian furniture industry, International Journal of Production Economics, 136, 1, 207-217, 2012.

[8] Snook S.C., Gorsuch R.L., Component analysis versus common factor analysis: A monte carlo study, Psychological Bulletin, 106, 1, 148, 1989.

[9] Tracey M., Tan C.L., Empirical analysis of supplier selection and involvement, customer satisfaction, and firm performance, Supply Chain Management: An International Journal, 6, 4, 174-188, 2001.

[10] Loppacher J.S., Cagliano R., Spina G., Key drivers of buyer-supplier relationships in global sourcing strategies, International Journal of Procurement Management, 4, 2, 156-180, 2011.

[11] Modi S.B., Mabert V.A., Supplier development: Improving supplier performance through knowledge transfer, Journal of Operations Management, 25, 1, 42-64, 2007.

[12] Nunnally J.C., Psychometric theory, 3ed, Tata McGraw-Hill Education, 2010.

[13] Pi W., Low C., Supplier evaluation and selection via taguchi loss functions and an AHP, The International Journal of Advanced Manufacturing Technology, 27, 5-6, 625-630, 2006.

[14] Churchill Jr G.A., Peter J.P., Research design effects on the reliability of rating scales: A metaanalysis, Journal of Marketing Research, 21, 4, 360$375,1984$.

[15] Weber C.A., A data envelopment analysis approach to measuring vendor performance, Supply Chain Management: An International Journal, 1, 1, 28-39, 1996.

[16] Sarkar A., Mohapatra P.K., Evaluation of supplier capability and performance: A method for supply base reduction, Journal of Purchasing and Supply Management, 12, 3, 148-163, 2006.

[17] Araz C., Ozkarahan I., Supplier evaluation and management system for strategic sourcing based on a new multicriteria sorting procedure, International Journal of Production Economics, 106, 2, 585-606, 2007.

[18] Jaber M.Y., Bonney M., Guiffrida A.L., Coordinating a three-level supply chain with learning-based continuous improvement, International Journal of Production Economics, 127, 1, 27-38, 2010.
[19] Petroni A., Braglia M., Vendor selection using principal component analysis, Journal of Supply Chain Management, 36, 2, 63-69, 2000.

[20] Heikkilä J., From supply to demand chain management: Efficiency and customer satisfaction, Journal of Operations Management, 20, 6, 747-767, 2002.

[21] Groves W., Collins J., Gini M., Ketter W., Agentassisted supply chain management: Analysis and lessons learned, Decision Support Systems, 57, 1, 274-284, 2014.

[22] Cho D.W., Lee Y.H., Ahn S.H., Hwang M.K., A framework for measuring the performance of service supply chain management, Computers \& Industrial Engineering, 62, 3, 801-818, 2012.

[23] Hair J., Anderson R., Tatham R., Black W., Multivariate Data Analysis, 5th ed. London, Prentice Hall, 1998.

[24] Heizer J.H., Render B., Operations management, Pearson Education India, 2008.

[25] Fahy J., A resource-based analysis of sustainable competitive advantage in a global environment, International Business Review, 11, 1, 57-77, 2002.

[26] Hammami R., Temponi C., Frein Y., A scenariobased stochastic model for supplier selection in global context with multiple buyers, currency fluctuation uncertainties, and price discounts, European Journal of Operational Research, 233, 1, 159-170, 2014.

[27] Ulaga W., Eggert A., Value-based differentiation in business relationships: Gaining and sustaining key supplier status, Journal of Marketing, 70, 1, 119136, 2006.

[28] Tabachnick B.G., Fidell L.S., Osterlind S.J., Using multivariate statistics, 4th Ed. New York: Allyn \& Bacon, 2001.

[29] Dou Y., Zhu Q., Sarkis J., Evaluating green supplier development programs with a grey-analytical network process-based methodology, European Journal of Operational Research, 233, 2, 420-431, 2013.

[30] Weber C.A., Current J.R., Benton W., Vendor selection criteria and methods, European Journal of Operational Research, 50, 1, 2-18, 1991a.

[31] Ho W., Xu X., Dey P.K., Multi-criteria decision making approaches for supplier evaluation and selection: A literature review, European Journal of Operational Research, 202, 1,16-24, 2010.

[32] Bryman A., Social research methods, Oxford university press, 2012.

[33] Missopoulos F.S., Dergiades T., Decisive factors for the adoption of just-in-time in greek SMEs: A pro- 
bit model, International Journal of Logistics Systems and Management, 3, 3, 344-355, 2007.

[34] Saraph J.V., Benson P.G., Schroeder R.G., An instrument for measuring the critical factors of quality management, Decision Sciences, 20, 4, 810-829, 1989.

[35] Fawcett S.E., Magnan G.M., McCarter M.W., Benefits, barriers, and bridges to effective supply chain management, Supply Chain Management: An International Journal, 13, 1, 35-48, 2008.

[36] Forker L.B., Mendez D., An analytical method for benchmarking best peer suppliers, International Journal of Operations \& Production Management, 21, 1/2, 195-209, 2001.

[37] Krause D.R., Pagell M., Curkovic S., Toward a measure of competitive priorities for purchasing, Journal of Operations Management, 19, 4, 497-512, 2001.

[38] Takeishi A., Bridging inter-and intra-firm boundaries: Management of supplier involvement in automobile product development, Strategic Management Journal, 22, 5, 403-433, 2001.

[39] Chen I.J., Paulraj A., Lado A.A., Strategic purchasing, supply management, and firm performance, Journal of Operations Management, 22, 5, 505-523, 2004.

[40] Gong Z., An economic evaluation model of supply chain flexibility, European Journal of Operational Research, 184, 2, 745-758, 2008.

[41] Droge C., Jayaram J., Vickery S.K., The effects of internal versus external integration practices on time-based performance and overall firm performance, Journal of Operations Management, 22, 6, 557-573, 2004.

[42] Lamming R.C., Cousins P.D., Notman D.M., Beyond vendor assessment: Relationship assessment programmes, European Journal of Purchasing \& Supply Management, 2, 4, 173-181, 1996.

[43] Lewis-Beck M., Factor analysis and related techniques/international handbooks of quantitative applications in social sciences, Sage, 1994.

[44] Saunders A.G., Supplier audits as part of a supplier partnership, The TQM Magazine, 6, 2, 41-42, 1994.

[45] Buffa J., Ittner C., Vendor rating puts profit in purchasing, Purchasing World, 31, 5, 40-41, 1987.

[46] Pallant J., SPSS survival manual: A step by step guide to data analysis using SPSS, Open University Press, 2010.

[47] Cousins P.D., Lawson B., Squire B., An empirical taxonomy of purchasing functions, International
Journal of Operations \& Production Management, 26, 7, 775-794, 2006.

[48] Vouzas F., Psychogios A., Assessing managers' awareness of TQM, The TQM Magazine, 19, 1, 62$75,2007$.

[49] Cebi F., Bayraktar D., An integrated approach for supplier selection, Logistics Information Management, 16, 6, 395-400, 2003.

[50] Pohl M., Förstl K., Achieving purchasing competence through purchasing performance measurement system design - A multiple-case study analysis, Journal of Purchasing and Supply Management, 17, 4, 231-245, 2011.

[51] Birch D., Made for each other, Supply Management, 42-43, 2001.

[52] Blaxter L., Hughes C., Tight M., How to research, McGraw-Hill International Inc, 2010.

[53] Shin H., Benton W., Jun M., Quantifying suppliers' product quality and delivery performance: A sourcing policy decision model, Computers \& Operations Research, 36, 8, 2462-2471, 2009.

[54] Szamosi L.T., Duxbury L., Development of a measure to assess organizational change, Journal of Organizational Change Management, 15, 2, 184-201, 2002 .

[55] Gunasekaran A., Patel C., McGaughey R.E., A framework for supply chain performance measurement, International Journal of Production Economics, 87, 3, 333-347, 2004.

[56] Lee C.H., Rhee B., Cheng T., Quality uncertainty and quality-compensation contract for supply chain coordination, European Journal of Operational Research, 228, 3, 582-591, 2013.

[57] Ohdar R., Ray P.K., Performance measurement and evaluation of suppliers in supply chain: An evolutionary fuzzy-based approach, Journal of Manufacturing Technology Management, 15, 8, 723-734, 2004 .

[58] Panayides P.M., Venus Lun Y., The impact of trust on innovativeness and supply chain performance, International Journal of Production Economics, 122, 1, 35-46, 2009.

[59] Nassimbeni G., Battain F., Evaluation of supplier contribution to product development: Fuzzy and neuro-fuzzy based approaches, International Journal of Production Research, 41, 13, 2933-2956, 2003.

[60] Robinson P.B., Stimpson D.V., Huefner J.C., Hunt H.K., An attitude approach to the prediction of entrepreneurship, Entrepreneurship Theory and Practice, 15, 4, 13-31, 1991. 
[61] Presutti Jr W.D., Mawhinney J.R., The supply chain-finance link, Supply Chain Management Review, 11, 6, 32-38, 2007.

[62] Stadtler H., Supply chain management and advanced planning - basics, overview and challenges, European Journal of Operational Research, 163, 3, 575-588, 2005.

[63] Uzzi B., Social structure and competition in interfirm networks: The paradox of embeddedness, Administrative Science Quarterly, 42, 1, 35-67, 1997.

[64] Mandal A., Deshmukh S., Vendor selection using interpretive structural modelling (ISM), International Journal of Operations \& Production Management, 14, 6, 52-59, 1994.

[65] Das K., Integrating effective flexibility measures into a strategic supply chain planning model, European Journal of Operational Research, 211, 1, 170-183, 2011.
[66] Choy K.L., Lee W., Lo V., Development of a case based intelligent customer-supplier relationship management system, Expert Systems with Applications, 23, 3, 281-297, 2002.

[67] Fredriksson P., Araujo L., The evaluation of supplier performance: A case study of volvo cars and its module suppliers, Journal of Customer Behavior, 2 , 3, 365-384, 2003.

[68] Inemek A., Matthyssens P., The impact of buyersupplier relationships on supplier innovativeness: An empirical study in cross-border supply networks, Industrial Marketing Management, 42, 4, 580-594, 2013.

[69] Wynstra F., Pierick E.T., Managing supplier involvement in new product development: A portfolio approach, European Journal of Purchasing \& Supply Management, 6, 1, 49-57, 2000.

[70] Završnik B., The importance of selection and evaluation of the supplier in purchasing management, Management (Split), 3, 2, 59-74, 1998. 